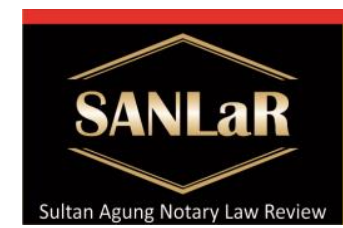

Volume 2 No. 4, December 2020

\section{Sultan Aqung}

Notary Law Review

The Position Of Legal Protection For...(Retno Sulistyowati)

\title{
The Position of Legal Protection for Debtors for Bankruptcy Conducted by Separatist Creditors in terms of Act No. 4 of 1996 concerning Mortgage Rights
}

\author{
Retno Sulistyowati *)
}

${ }^{*}$ Student of Master of Notary Law, Faculty of Law, Universitas Islam Sultan Agung (UNISSULA) Semarang, E-mail: retnosusilowati@gmail.com

\begin{abstract}
The purpose of this research is to know and analyze; 1). The current implementation of debtor legal protection for bankruptcy is carried out by separatist creditors. 2) Factors that influence the implementation of debtor's legal protection for bankruptcy carried out by separatist creditors. 3) The proper implementation of debtor legal protection for bankruptcy by separatist creditors. This study uses a normative juridical research method, using a statutory approach and a conceptual approach. This type of research is descriptive analytical. The data collection technique is the literature study of this thesis. The data analysis method is descriptive qualitative analytical. The results show that: 1. The implementation of the Bankruptcy Law has not provided protection to debtors, because: The requirements for requesting a bankruptcy statement make it easier for the debtor to be declared bankrupt, even though the debtor is actually in a solvent condition; The PKPU mechanism has not provided broad opportunities for debtors to improve company performance; and Efforts in bankruptcy are dominated by the authority of creditors. 2. Factors that influence the implementation of debtor's legal protection against bankruptcy carried out by separative creditors are: There are no funds for the costs of managing and settling bankruptcy assets; Bankrupt Debtor is not cooperative; and The debtor sells/transfers his assets before being declared bankrupt. 3. The Bankruptcy Law in future requires an insolvency test. This is based on reasons to prevent debtors whose assets are more than their debts being declared bankrupt by the court.
\end{abstract}

Keywords: Legal Protection; Debtors; Bankruptcy; Separatist Creditors.

\section{Introduction}

In the event that the lending institution is a pawn, the valuable object as collateral is like gold. In the case of fiduciary security, which is a special agreement entered into between a debtor and creditor to agree on the following matters: ${ }^{1}$

1. Material guarantees, namely the existence of certain objects used as collateral.

2. Collateral of an individual or personal nature, namely the existence of certain people who are able to pay or fulfill the debtor's performance if the debtor fails to promise.

\footnotetext{
${ }^{1}$ Albertus, Andreas. (2010). "Hukum Fidusia". Malang: Selaras. p. 31
} 
In order to protect the rights and obligations of each party (debtors and creditors), the Bankruptcy and PKPU Law was issued. The Bankruptcy Law and PKPU are the amendments to Act No 4 of 1998 concerning Stipulation of Government Regulations in Lieu of Act No 1 of 1998 concerning Amendments to the Law on Bankruptcy to Law.

A debtor can be declared bankrupt if the debtor has two or more creditors and does not pay in full at least one receivable that is overdue and can be collected (Article 2 paragraph (1) of the Bankruptcy Law and PKPU). Meanwhile, the postponement of the payment of receivables (PKPU) is concentrated to provide opportunities for debtors who, at maturity, are not yet able to pay the receivables but may be able to pay the receivables at a later date. In other words, PKPU is an alternative method provided to debtors to ease the burden of paying debts to creditors with an extension for a certain period. Of course, the determination of the time limit for the extension of the payment of receivables is based on the agreement of the two parties, namely the creditor and the debtor. This model is also known as the concept of debt restructuring ${ }^{2}$.

The concept of debt restructuring is regulated in Article 222 of the Bankruptcy and PKPU Law which reads: ${ }^{3}$

Article 222

(1) Postponement of Accounts Receivable Payment obligation is submitted by a Debtor who has more than 1 (one) creditors or by creditors;

(2) The debtor who is unable or predicts that he will not be able to continue to pay his receivables which are past due and which can be collected, can request a postponement of the payment of receivables, with the intention of submitting a reconciliation plan which includes an offer to pay part or all of the receivables to creditors;

(3) Creditors who predict that the debtor is unable to continue to pay their overdue and collectible receivables can request that the debtor be granted a deferment of the debt payment obligations, to enable the debtor to submit a settlement plan that includes an offer to pay part or all of the receivables to his creditors.

Based on the contents of Article 222 of the Bankruptcy and PKPU Law, both creditors and debtors can apply for a postponement of their debt payment obligations. However, the fact is that the existence of creditors who can apply for a postponement of the obligation to pay receivables creates problems.

Another major problem today, can be seen in Article 2 (paragraph 1) of Act No 37 of 2004 concerning irrational bankruptcy requirements because bankruptcy applications can be filed and a bankruptcy decision by the Commercial Court can be handed down against debtors who are still solvent. namely debtors whose total assets are greater than the total receivables). With such bankruptcy conditions, it is very difficult to achieve legal certainty and the objective of implementing the Fair Bankruptcy Law. In addition, Act No 37 of 2004 pays more attention to and protects the interests of

\footnotetext{
2 Darmadji, Tjiptono. (2001). estrukturisasi: Memulihkan dan Mengakselerasi Ekonomi Nasional. Jakarta: Grasindo. p. 69.

${ }^{3}$ Article 222 of the Bankruptcy Law and PKPU
} 
bankrupt creditors than the interests of bankrupt debtors which should also be protected. ${ }^{4}$

The conditions for bankruptcy as referred to in Article 1 "Faillissements-Verordening" (Bankruptcy Law), which took effect on November 1, 1906, even though only provided the possibility to file a bankruptcy petition against a debtor in disability (Van de voorziening in geval van onvermogen van kooplieden ) or not being able to be real (kennelijk onvermogen) so that they are in a state to stop paying back their receivables. This means that the debtor is already in a state of insolvency (greater liabilities than assets and his/her cheeks), ${ }^{5}$ Meanwhile, for debtors who are still solvent (their liabilities are smaller than their assets and cheeks), the curator should ask the debtors to jointly find solutions to pay off their obligations by fixing management, for example, curators and debtors conduct independent audits to find out debtor problems so that curators do not directly to settle the assets of the bankrupt debtor. ${ }^{6}$ In its development, the debtor's position which was bankrupt by the priority rights of the creditors resulted in injustice, especially in terms of debtor legal protection. So it is interesting if a deeper study is carried out related to "The Position of Legal Protection of Debtors for Bankruptcy Conducted by Separatist Creditors in terms of Act No 4 of 1996 concerning Mortgage Rights in Madiun City".

This researchattempted answering the problem regarding the implementation of debtor legal protection for bankruptcy carried out by separatist creditors at this time, the factors that influence the implementation of debtor legal protection for bankruptcy carried out by separatist creditors and the implementation of debtor legal protection for bankruptcy carried out by separatist creditors.

\section{Research Methods}

The approach method used in this research is the normative juridical approach method. Specification of research used is descriptive analytical, which describes the applicable laws and regulations in relation to legal theories and their implementation practices. ${ }^{7}$ Primary and secondary data sources obtained by interview and study document methods. Data analysis using qualitative analysis.

\section{Results and Discussion}

\subsection{Implementation of Debtor Legal Protection for Bankruptcy Conducted by Separatist Creditors}

Protection concept law according to Philipus M Hadjon is a collection of rules or rules that can protect one thing from another. In relation to the relationship between debtors and creditors, it means that the law provides protection for the debtor's rights

\footnotetext{
${ }^{4}$ https://www.hukumonline.com/pusatdata/detail/320/node/19/undangundang-nomor-4-tahun-1998/, accessed on 11 January 2020 at 22:15 WIB.

${ }^{5}$ Soejartin, Drs. lur. R. Hukum Dagang I dan II, Penerbit Pradnya Paramita. p. 263.

${ }^{6}$ Loc.cit

${ }^{7}$ Suryabrata, Sumardi. (1993). Metodologi Penelitian. Jakarta: Rajawali. p. 19
} 
from something that results in the fulfillment of these rights. In connection with the foregoing, in accordance with the 1945 Constitution Article 28 D Paragraph (1) it is stated that "everyone has the right to recognition, guarantee, protection and legal certainty that is just and equal treatment before the law". This provision means that the law requires legal protection and legal certainty that contains justice in a regulation.

According to the author, the unfairness of the bankruptcy requirements against the debtor is quite clearly known in the manufacture of bankruptcy legislation products. The protection of creditors' interests is increasingly assertive in Act No 37 of 2004. Prior to that, substantively, both Faillions of the Law and Act No 4 of 1998 were pro to the interests of creditors. This can at least be seen from the provisions relating to the requirements for a declaration of bankruptcy, suspension of debt payment obligations, and provisions regarding other actions for the benefit of creditors. Creditors can easily apply for a bankruptcy statement against their debtors, because the condition is that there are two or more creditors who do not pay off at least one debt that is due and can be collected.

Weaknesses The bankruptcy law is a scourge for justice seekers, especially debtors as defendants and creditors as applicants for bankruptcy. Judging from the history of its controversial presence, it can be understood that the current bankruptcy law is the result of a "grafting" process between old regulations and new ideas in special procedural law, so that in its application there are matters that are unclear in its regulations and lead to various interpretations. , even a legal vacuum for resolution. In addition, article 2 paragraph (1) UURI No. 37 of 2004 only gives authority to the commercial court to examine and decide bankruptcy cases, including:

1. The procedural problem in the application of the bankruptcy law is, for example, related to the provisions of article 91 of the Bankruptcy Law which stipulates that the implementation of bankruptcy assets remains valid and has legal force, even though there are legal remedies which then invalidate the decision regarding the bankruptcy statement. As a result, it raises the problem of who will be sued in relation to the losses that have occurred, as well as what form of legal protection to the borrower whose decision has been canceled, while the assets have been properly executed and controlled by a third party. ${ }^{8}$

2. Distrust of the Commercial Court; that is, the decision of the Commercial Court often fails implemented because there are no clear legal rules in responding to it. As a result of bankruptcy, debtor assets are placed in general confiscation or transfer of management rights and settlement of bankrupt assets to the curator, immediately after the debtor is declared bankrupt (article 16, paragraph 2) of the Bankruptcy Law. But many debtors don't care and the supervisory judge doesn't work. This is exacerbated by the reluctance of the commercial courts to use coercive bodies. ${ }^{9}$

So that it determines who is entitled to the claim against the bankrupt debtor's assets, including the big problem in bankruptcy. Because in the bankruptcy process, the most essential is actually the distribution of the assets of the bankrupt debtor to his

\footnotetext{
${ }^{8}$ Sutedi, Adrian. (2009). Hukum Kepailitan. Jakarta: Ghalia Indonesia. p. 14.

${ }^{9}$ Ibid.
} 
creditors. Separatist creditors or special class creditors. Separatist creditors or special class creditors are creditors who can exercise their rights as if there was no bankruptcy (Article 55 UUK). This special class of creditors can sell their own goods that are collateral for debt as if there is no bankruptcy. From the proceeds from the sale, the creditors took the amount of the debt as repayment, while the rest was deposited with the curator. If it turns out that the proceeds from the sale are less than the amount owed, then he can combine himself as a concurrent creditor for the remainder. ${ }^{10}$

Separatist creditors have certain ties and their rights are guaranteed by certain agreements, therefore their position is outside bankruptcy. This means that they are not verified but put in the distribution list and registered with the Curator. Meanwhile, those including preferred creditors and concurrent creditors must be verified at the verification meeting and included in the distribution list.

Separatist creditors who relinquish their rights to execute collateral themselves as if there was no bankruptcy or whose rights to execute have ended, namely 2 (two) months after insolvency, are paid by the Curator from the proceeds from the sale of bankruptcy goods which are collateral for the receivables amounting to the value of the Insurance Right/Pawn/Fiduciary. If the sales proceeds are less than the value of the Mortgage/Pawning/Fiduciary Rights, the shortfall will become a concurrent claim, and if it turns out that the sales proceeds exceed the excess, the excess will be included in bankruptcy assets. Likewise, if a separatist creditor exercises his own execution rights, then he/she is only entitled to take an amount equal to the value of the Mortgage/Fiduciary Rights and the excess must be submitted to the Curator to become bankruptcy assets.

\subsection{Factors Influencing the Implementation of Debtor Legal Protection for Bankruptcy Conducted by Separative Creditors}

Factors that influence the implementation of debtor legal protection for bankruptcy carried out by separative creditors are: ${ }^{11}$

1. There are no funds for the costs of managing and settling bankruptcy assets.

The settlement of a bankruptcy requires a lot of funds, once the Curator receives the decision on the bankruptcy statement from the Commercial Court in a relatively short time, he must prepare funds for the announcement of the summary of the bankruptcy declaration decision and the deadline for submitting creditors' invoices/organizing accounts receivable matching meetings. The announcement as regulated in Article 15 paragraph (4) and Article 114 requires funds of more than IDR 10,000,000 (ten million rupiah) and there is no post in the routine budget of the Heritage Hall.

The UUK has actually anticipated the possibility of difficulties/obstacles for the Curator in financing to carry out the management and settlement of bankruptcy assets with the existence of Article 107 paragraph (1) mentioned above. Implementation in the field of selling bankruptcy assets takes time because they are demanded to sell at the maximum price so as not to cause loss of bankruptcy assets, besides that there must

\footnotetext{
10 Sudradjat, Agus. (1996). Kepailitan Dan Kaitannya Dengan Lembaga Perbankan, National Seminar Paper on Bankruptcy Institutions in Economic Law Reform in Indonesia, Semarang: Fakultas Hukum Universitas Katolik Soegijapranata. p. 4.

11 Rahmadewi, Maria Regina Fika. (2007). Penyelesaian Utang Debitur Terhadap Kreditur Melalui Kepailitan. Thesis. Magister Kenotariatan Undip. p. 89-91.
} 
be a permit from the Supervisory Judge which means that obtaining this permit also takes time, while the funds must be met immediately.

2. Bankrupt Debtor is not cooperative.

The curator needs data on the assets of the Debtor to record bankruptcy assets as regulated in Article 100 paragraph (1) of the UUK which states: "The curator must record bankruptcy assets no later than 2 (two) days after receiving the decision of his appointment as Curator."

Bankrupt debtors who are not cooperative in providing data on their assets will make it difficult for the curator to record bankruptcy assets. The bankrupt debtor who is not present at the receivables matching meeting which has been set up will result in postponement of the accounts receivable matching meeting. Pursuant to Article 121 paragraph (1) the presence of a bankrupt Debtor is mandatory, so that if the bankrupt Debtor is not present at the meeting of accounts receivable, the meeting cannot be continued and the Supervisory Judge will postpone it. The postponement of the accounts receivable matching meeting will increase the length of time for the bankruptcy settlement.

3. Bankrupt Debtor sells/hides his assets before being declared bankrupt.

The task of the Curator is to carry out the management and/or settlement of bankruptcy assets, so that if there is a Bankrupt Debtor's asset that was sold prior to bankruptcy, the Curator must take care of when to sell it and to whom the asset was sold. Tracking the assets of the Debtor that have been sold/hidden and the cancellation process takes a long time and costs a lot, this is clearly an obstacle in settling Debtor's debt to Creditors through bankruptcy.

Efforts that can be made to overcome the factors in the implementation of debtor legal protection against bankruptcy are as follows: ${ }^{12}$

\subsection{Implementation of Legal Protection for Debtors for Bankruptcy by Separatist Creditors}

Likewise with other provisions such as actio paulana, proof of fictitious creditors, and lawsuits against the directors which caused the company to go bankrupt due to negligence or wrongdoing, as well as abuse of authority by shareholders, the proof is not simple. Likewise, creditors who commit defaults and frauds such as in the PT DAB bankruptcy case which was filed for bankruptcy by PT Industama Karsa Mandiri, from decision Number: 20/Pailit/PN.Niaga.Sby, for that an insolvency test is the right alternative for replaces simple proof in determining whether a debtor can be declared bankrupt or not. When the debtor submits himself or is submitted by another party to be declared bankrupt at the Commercial Court, ${ }^{13}$ From the point of view of accounting, an insolvent condition is if the recorded assets/assets are not sufficient to pay off existing company liabilities, in general for the corporation it will be seen from the

\footnotetext{
12 Rahmadewi, Maria Regina Fika. (2007). Penyelesaian Utang Debitur Terhadap Kreditur Melalui Kepailitan, Thesis, Magister Kenotariatan Undip. p. 92

13 Ibid, p. 422.
} 
aggregate/collection side where a company/partnership is declared insolvent if the company's assets are insufficient. to pay off company obligations. ${ }^{14}$

The issue of insolvency is essential and crucial in bankruptcy law. The new Commercial Court can issue a statement verdictbankrupt if the debtor is in a state of insolvency. Insolvency is one of the criteria for declaring bankruptcy.

Thus the insolvency test really needs to be done so that it can be known with certainty and scientifically (from an economic/financial point of view) that the debtor is truly unable to pay. his debts. Bankruptcy Law No. 37 of 2004 does not require this insolvency test to be carried out, where as long as it is proven that the debtor has not paid and a technical examination has not been carried out whether the debtor in question is eligible to be declared bankrupt or not (insolvency test) also does not question whether due to inability, unwillingness or still sufficiently healthy financial condition or has been insolvent, the debtor may be declared bankrupt by the Commercial Court Decision. ${ }^{15}$

Substitution of the Bankruptcy Act from the Act Faillismensverdoning (staatblad Number 1906 Number 348) which remained in effect until 1998. Then Act No 4 of 1998 concerning Stipulation of Government regulations in lieu of Act No 1 of 1998 concerning Amendments to the Law on bankruptcy was enacted into Law. Furthermore, Act No 37 of 2004 replaced Act No 4 of $1998 .^{16}$

Based on the two laws above, in practice the protection of creditors is very strict. This can be seen in the provisions of the requirements for a bankruptcy and PKPU declaration and other provisions, such as general confiscation, Pauliana action, and gezejling. If it is related to debt relief (discharge), it cannot be given to each individual debtor, debt relief at least given to a debtor who has good faith, but he is unlucky because he cannot pay off his debts. Debt relief criteria for debtors in good faith can be found in several countries.

\section{Closing}

\subsection{Conclusion}

1. The implementation of the Bankruptcy Law has not provided protection to debtors, because:

a. The requirements for requesting a bankruptcy statement make it easier for the debtor to be declared bankrupt, even though the debtor is actually in a solvent condition;

b. The PKPU mechanism has not provided broad opportunities for debtors to improve company performance;

\footnotetext{
${ }^{14}$ Kusumati, Yuli Noor \& Sri Opti. (2005). Akuntansi Keuangan Lanjutan I. STEKPI YAPPINDO. Cetakan ke I. p. 96.

15 Natigor, Togar. (2008). Perlindungan Hukum Terhadap Debitur Dalam Proses Kepailitan dan Pemberesaan Budel Pailit. Thesis. Magister Hukum UI. p. 120

${ }^{16}$ Anisah, Siti. "Studi Komperatif Terhadap Perlindungan Kepentingan Kreditor dan Debitor dan Debitor dalam Hukum kepailitan” , Jurnal Hukum. No. Special Edition Vol. 16 October 2009 30-50.
} 
c. Efforts in bankruptcy are dominated by the authority of creditors.

2. Factors that influence the implementation of debtor legal protection for bankruptcy carried out by a separative creditor are that there is no funds for the management and settlement of bankruptcy assets, the Bankrupt Debtor is not cooperative, and the debtor sells/transfers his assets before being declared bankrupt.

3. The Bankruptcy Law in the future requires an insolvency test. This is based on the reason to prevent a debtor whose assets are more than his debt is declared bankrupt by the court. A person is considered solvent if and only if that person can pay off his overdue and collectible debt. The debtor is also considered solvent if the debtor's assets do not exceed the debt.

\subsection{Suggestion}

The government needs to amend Act No 37 of 2004 concerning Bankruptcy and PKPU in order to accommodate the interests of debtors and provide legal protection for debtors.

\section{References}

Journals:

Anisah, Siti. "Studi Komperatif Terhadap Perlindungan Kepentingan Kreditor dan Debitor dan Debitor dalam Hukum kepailitan", Jurnal Hukum. No. Special Edition Vol. 16 October 2009 30-50.

Books:

[1] Andreas. (2010). "Hukum Fidusia". Malang: Selaras.

[2] Darmadji, Tjiptono. (2001). Restrukturisasi: Memulihkan dan Mengakselerasi Ekonomi Nasional. Jakarta: Grasindo.

[3] Kusumati, Yuli Noor \& Sri Opti. (2005). Akuntansi Keuangan Lanjutan I. STEKPI YAPPINDO. Cetakan ke I.

[4] Natigor, Togar. (2008). Perlindungan Hukum Terhadap Debitur Dalam Proses Kepailitan dan Pemberesaan Budel Pailit. Thesis. Magister Hukum UI.

[5] Rahmadewi, Maria Regina Fika. (2007). Penyelesaian Utang Debitur Terhadap Kreditur Melalui Kepailitan. Thesis. Magister Kenotariatan Undip.

[6] Rahmadewi, Maria Regina Fika. (2007). Penyelesaian Utang Debitur Terhadap Kreditur Melalui Kepailitan, Thesis, Magister Kenotariatan Undip.

[7] Soejartin, Drs. lur. R. Hukum Dagang I dan II, Penerbit Pradnya Paramita.

[8] Sudradjat, Agus. (1996). Kepailitan Dan Kaitannya Dengan Lembaga Perbankan, National Seminar Paper on Bankruptcy Institutions in Economic Law Reform in Indonesia, Semarang: Fakultas Hukum Universitas Katolik Soegijapranata. 
[9] Suryabrata, Sumardi. (1993). Metodologi Penelitian. Jakarta: Rajawali.

[10] Sutedi, Adrian. (2009). Hukum Kepailitan. Jakarta: Ghalia Indonesia.

Internet:

https://www.hukumonline.com/pusatdata/detail/320/node/19/undangundangnomor-4-tahun-1998/, accessed on 11 January 2020 at 22:15 WIB. 